\title{
Efek Kombinasi Latihan Eccentric dan Neuromuscular Electrical Stimulation (NMES) pada Daya Tahan Otot Tungkai Pemain Badminton Amatir: Case Report
}

\author{
Farid Rahman¹, Ilham Setya Budi², Aqzal Dwi Kuncoro ${ }^{3}$
}

\author{
1,2Universitas Muhammadiyah Surakarta \\ 3Politeknik Kesehatan Kemenkes Surakarta \\ fr280@ums.ac.id1, ilhamsetya37@gmail.com², aqzalkuncoro25@gmail.com³
}

\author{
ABSTRAK \\ Diajukan 19 Desember 2020 Diperbaiki 9 Februari 2021 Diterima 10 Februari 2021
}

Latar Belakang: Badminton merupakan olahraga dengan intensitas tinggi dan gerakan mendadak berubah arah. Pemain diharuskan memiliki kondisi fisik yang baik untuk menunjang kelincahan gerakan tungkai, jumping, dan keseimbangan.

Tujuan: Mengetahui efek kombinasi latihan eccentric dan NMES pada daya tahan otot tungkai pemain badminton amatir.

Metode: Menggunakan single-subject research yang dilakukan terhadap seorang atlet badminton amatir berumur 18 tahun dan profil tinggi badan $172 \mathrm{~cm}$ dan berat badan $56 \mathrm{~kg}$. Subjek diberikan kombinasi latihan eccentric dan NMES selama 4 minggu yang dilakukan 3x/minggu dan dilakukan follow up pengukuran daya tahan tungkai selama 1 bulan.

Hasil: Evaluasi pengukuran daya tahan otot tungkai menggunakan wall sit test, baseline didapatkan 53,2 detik yang masuk dalam kategori below average. Hasil meningkat setelah diberikan latihan dan dievaluasi saat latihan menjadi 178 detik yang masuk dalam kategori excellent dan ketika dilakukan follow up selama 1 bulan didapatkan hasil 226 detik yang masuk dalam kategori excellent.

Kesimpulan: Terdapat peningkatan signifikan pada daya tahan otot tungkai pemain badminton amatir setelah pemain diberikan kombinasi latihan eccentric dan NMES selama 1 bulan dan pengaruh jangka panjang terlihat ketika follow up selama 1 bulan dilakukan.

Kata Kunci: Latihan eccentric; NMES; daya tahan tungkai; badminton; wall sit test

\section{ABSTRACT}

Background: Badminton is a high-intensity sport and sudden movement. Players are required to be in good physical condition to support agility with leg movements, jumping, and balance.

Objective: Determine the effect of eccentric and NMES combination training on leg muscle endurance of an amateur badminton player.

Method: Used single-subject research that was conducted on an amateur badminton athlete aged 18 years with $172 \mathrm{~cm}$ height and $56 \mathrm{~kg}$ weight. The subject was given a combination of eccentric and NMES exercises for 4 weeks carried out 3 times/week and follow-up measurement of leg endurance for 1 month.

Results: Evaluation of leg muscle endurance measurement using wall sit test, baseline obtained 53.2 seconds which was included in the below-average category. The results increased after being given exercise and evaluated at exercise to 178 seconds which was included in the excellent category and when the follow-up was carried out for 1 month, the result was 226 seconds which was in the excellent category.

Conclusion: There was a significant increase in leg muscle endurance of the subject after eccentric and NMES combination training was given for 1 month and the long-term effect was observed when the 1-month follow-up was carried out.

Keywords: Eccentric Exercise; NMES; Leg Muscle Endurance; Badminton; Wall Sit Test 
PENDAHULUAN

Badminton merupakan olahraga yang paling digemari di kalangan masyarakat baik anak muda maupun orang tua. Olahraga ini menuntut pemain untuk memiliki unsur kondisi fisik prima seperti kekuatan, koordinasi, fleksibilitas, daya tahan otot tungkai, serta daya tahan fisik yang baik (Akbari et al., 2018).

Permainan badminton memiliki ciri khas dimainkan dengan intensitas tinggi dan gerakan yang mendadak berubah arah. Dalam mempertahankan permainan dengan intensitas tinggi, pemain harus pandai mengatur tenaga guna mempertahankan efisiensi pengeluaran energi (Phomsoupha \& Laffaye, 2015).

Di sisi lain, pemain harus mampu mengkoordinasikan gerakan antara lengan atas dan kaki, gerakan melangkah dan mengarahkan shuttlecock, pengaturan melangkah mempertimbangkan fungsi biomekanik yang berfungsi dalam melompat, gerakan lunges, dan mempertahankan posisi ketika bergerak (Phomsoupha \& Laffaye, 2015).

Pemain badminton amatir merupakan pemain yang belum terlatih sehingga memiliki pukulan, langkah kaki, dan lompatan yang belum terampil atau luwes. Biasanya, pemain badminton amatir hanya terfokus pada pergerakan shuttlecock (Wong et al., 2019).

Selain itu, pemain badminton amatir seringkali tidak menghiraukan latihan daya tahan otot tungkai bawah. Dampaknya, mereka membuat gerakan tungkai untuk menggapai shuttlecock yang tidak bisa lincah dan landing ketika loncatan tidak seimbang (Wong et al., 2019).

Padahal, gerakan tungkai dan jumping merupakan komponen utama dalam permainan badminton untuk menyerang dan bertahan. Daya tahan otot tungkai bawah yang lemah membuat pemain sulit menjaga keseimbangan dan dapat meningkatkan risiko cedera (Wong et al., 2019).
Gerakan jumping merupakan komponen penting saat melakukan smash yang digunakan dalam permainan menyerang. Gerakan jumping memerlukan kontraktilitas pada otot dan kekuatan otot tungkai bawah karena, pada posisi landing, sendi mengalami pembebanan yang berlebih sehingga memerlukan daya tahan otot, baik untuk menjaga keseimbangan dan mengurangi risiko cedera (Huang et al., 2019).

Gerakan tungkai atau footwork merupakan keterampilan paling dasar dalam permainan badminton. Gerakan ini memungkinkan perpindahan cepat ke depan, tengah, samping, dan belakang yang menyumbang $15 \%$ dari semua gerakan selama pertandingan berlangsung (Hong et al., 2014).

Keterampilan footwork memudahkan pemain untuk menggapai shuttlecock, menjaga keseimbangan dinamis tubuh, dan menurunkan risiko cedera pada ekstremitas bawah (Hong et al., 2014). Faktor penentu kinerja gerakan kaki lunges adalah kekuatan otot tungkai bawah, fleksibilitas otot, ketahanan otot tungkai bawah, dan kelincahan dari pemain (Fu et al., 2017).

Latihan daya tahan otot penting untuk pemain badminton. Salah satu latihan daya tahan otot tungkai bawah mengadopsi prinsip eccentric exercise berupa lunge dan squat. Latihan eccentric melibatkan fase eksentrik (pemanjangan otot) dan konsentrik (pemendekan otot). Penerapan latihan ini melibatkan mekanisme Stretch Shortening Muscle Cycle (SSC) dan co-contraction dari kelompok otot hamstring dan quadriceps (Carzoli et al., 2019).

Ketika otot bekerja fase eksentrik secara cepat, hal ini akan memberikan respons balik berupa peningkatan kecepatan kinerja otot untuk bergerak konsentrik. Hal tersebut akan mempengaruhi peningkatan dari lingkup gerak sendi lutut dan respons proprioseptif di dalam sendi lutut yang berpengaruh 
terhadap keseimbangan (Carzoli et al., 2019).

Peningkatan sudut fleksi lutut, baik dari gerakan squat maupun lunge, menghasilkan sensibilitas reseptor proprioseptif yang lebih banyak. Hal ini terjadi ketika muscle spindle saat ekstensor lutut dirangsang oleh pemanjangan otot, kecepatan, dan percepatan ketika sudut fleksi meningkat (Lai et al., 2018). Pelatihan eccentric pada badminton dapat meningkatkan keseimbangan landing dari jumping, kelincahan kaki berguna dalam berpindah secara cepat, dan mampu meningkatkan daya ledak otot ketika jumping serta menjangkau shuttlecock.

Upaya meningkatkan daya tahan otot tungkai bawah dapat difasilitasi dengan modalitas fisioterapi berupa Neuromuscular Electrical Stimulation (NMES). NMES merupakan suatu metode yang mampu memfasilitasi kontraksi otot melalui kedutan yang dihasilkan dari stimulasi listrik, yang memiliki fungsi mendepolarisasi motor neuron dari terminal akson (Neyroud et al., 2017).

Pemberian NMES mampu mengurangi stres beban mekanik yang berada di persendian. Kontraksi yang ditimbulkan berupa kontraksi volunter, ketika kontraksi yang timbul akibat NMES akan lebih besar dari kontraksi volunter yang dihasilkan oleh otot. Hal ini berdampak pada banyaknya motor unit yang dihasilkan otot (Neyroud et al., 2017).

NMES yang dikombinasikan dengan latihan eccentric squat dan lunge dapat memberikan efek pada pelepasan motor neuron yang lebih besar. Hal ini sangat bermanfaat pada daya tahan otot dan meningkatkan fleksibilitas otot (Lepley et al., 2015).

Peningkatan daya tahan otot dan fleksibilitas otot diharapkan mampu meningkatkan perbaikan pola gerakan kaki yang dapat menunjang performa pemain baik dalam bertahan maupun menyerang badminton. Dengan demikian, tujuan dari studi ini adalah untuk mengetahui efek kombinasi latihan eccentric dan NMES pada daya tahan otot tungkai pemain badminton amatir.

\section{METODE PENELITIAN}

Studi yang dilakukan pada saat ini menggunakan single-subject research dengan pendekatan desain ABA. Desain ini untuk mengetahui manfaat efek kombinasi latihan eccentric dan NMES pada daya tahan otot tungkai pemain badminton amatir: Case Report. Desain penelitian ABA dapat dilihat melalui gambar di bawah ini.

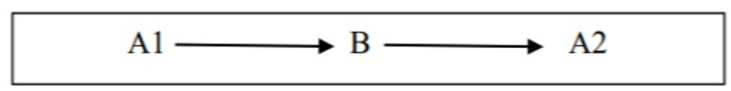

Gambar 1. Desain Penelitian ABA

Keterangan:

- A1: Baseline yaitu pemeriksaan kondisi daya tahan otot tungkai dengan menggunakan instrumen wall squat test yang diukur sebanyak tiga kali dalam rentang waktu tertentu

- B: Pemberian intervensi (kombinasi NMES dan Eccentric Squat Exercise) selama 4 minggu kemudian dilakukan evaluasi setelah treatment berakhir.

- A2: Follow up yaitu pemeriksaan kembali atau evaluasi yang meliputi setelah tidak terpapar program treatment satu bulan berikutnya.

Lokasi penelitian dilaksanakan di Desa Blimbing, Kecamatan Gatak, Kabupaten Sukoharjo, Provinsi Jawa Tengah. Waktu pelaksanaan studi adalah 1 Juni 2020 sampai dengan 30 Juli 2020. Studi dilaksanakan terhadap seorang pemain badminton amatir berumur 18 tahun dengan profil tinggi badan $172 \mathrm{~cm}$ dan berat badan (BB) $56 \mathrm{~kg}$ yang pernah tergabung dalam PB Avatar dan Pusaka putih. Subjek penelitian sudah aktif mengikuti kegiatan badminton selama 8 tahun. Kriteria inklusi dan ekslusi pemilihan subjek adalah sebagai berikut:

a. Kriteria inklusi:

1. Subjek berumur 18-26 tahun 
2. Sudah aktif bergabung dalam kegiatan bulu tangkis minimal 5 tahun

3. Memiliki jadwal latihan yang minimal dua kali seminggu

b. Kriteria Ekslusi:

1. Memiliki riwayat cedera kurang dari tiga bulan

2. Skor wall squat test $>60$ detik

Tahapan studi dimulai dengan baseline yang dilakukan sebanyak tiga kali pada tanggal 01, 03, dan 05 Juni dengan menggunakan instrumen pengukuran yang dinamakan dengan wall squat test. Definisi operasional intervensi terdiri dari:

\section{a. Leg Eccentric Exercise}

Program latihan pada tungkai yang terdiri dari latihan knee squat dan forward lunge dengan menggunakan prinsip kontraksi eksentrik saat latihan dilakukan.

b. Latihan Squat

Latihan Squat adalah latihan dengan subjek yang menurunkan paha/ hip dari posisi berdiri dan kemudian kembali berdiri. Selama fase squat, hip, dan knee dalam gerakan fleksi sedangkan ankle pada gerakan dorsofleksi sebaliknya saat fase kembali berdiri persendian hip dan knee melakukan gerakan ekstensi dan sendi ankle melakukan gerakan plantar fleksi.

Latihan Forward Lunges dan Squat program intervensi disusun berdasarkan kaidah FITT yang meliputi Frekuensi, Intensitas, Time, Type (Tabel 1).

c. Neuromuscular Electrical Stimulation (NMES)

Sebuah perangkat elektrikal stimulasi yang memberikan impuls ke saraf dengan input yang akan menyebabkan otot berkontraksi (Tabel 2).

d. Daya tahan otot tungkai

Daya tahan otot tungkai adalah kemampuan otot tungkai (secara umum) untuk mempertahankan kontraksi yang berulang melawan tahanan selama beberapa waktu tertentu. Dalam studi ini, instrumen pengukuran menggunakan "Wall Squat Test". Berikut ini rangkaian tata cara pengukuran daya tahan otot tungkai.

1. Alat dan bahan
a) Permukaan rata
b) Stopwatch

2. Prosedur

a) Berdiri dengan bahu dibuka selebar bahu dengan jarak dua kaki dari permukaan dinding

b) Pelan-pelan turunkan badan sampai membentuk sudut knee dan hip 900. Pastikan kaki benarbenar flat pada permukaan.

c) Pencatatan waktu dimulai saat subjek mempertahankan posisi dengan baik.

\section{Scoring}

Pendokumentasian total waktu saat mempertahankan posisi dan interpretasi Wall Sit Test menggunakan satuan detik (Tabel 3).

Analisis dan pengolahan data pada studi ini menggunakan pendekatan statistik deskriptif berupa gambaran proses kemajuan atau progresifitas outcome dalam hal ini daya tahan otot tungkai. Penyajian dalam studi ini menggunakan grafik dan tabel. Grafik yang ditunjukan mendeskripsikan tingkat efek program kombinasi latihan eccentric dan NMES terhadap daya tahan otot tungkai subjek atlet amatir badminton.

Proses analisis data dibutuhkan dalam setiap kondisi yang ada dengan komponen yang perlu diperhatikan, yaitu variabel yang diubah, perubahan stabilitas, serta efek yang muncul serta data yang bersifat tumpang tindih. Pengukuran baseline atau A1 dilakukan sebanyak 3 kali sampai data stabil. Sesi ini dilakukan selama satu minggu untuk melihat daya tahan otot tungkai sebelum intervensi dilakukan dengan 
Efek Kombinasi Latihan Eccentric dan Neuromuscular Electrical...

menggunakan instrumen wall sit test.

Fase kedua dalam penelitian ini adalah intervensi selama empat minggu. Fase selanjutnya adalah evaluasi atau A2 untuk mengidentifikasi keberhasilan intervensi dengan evaluasi daya tahan otot tungkai. Kemudian, pengukuran follow up diberikan untuk mengetahui keberhasilan program terhadap kondisi daya tahan otot tungkai setelah tidak mendapatkan paparan intervensi.

Tabel 1 menggambarkan program latihan dengan menggunakan teknik latihan eksentrik (forward lunge dan squat) untuk subjek yang disusun berdasarkan prinsip progresif secara bertahap.

Program dilaksanakan selama empat minggu dengan prinsip progresivitas yang diletakkan pada penambahan set secara teratur, dengan mempertimbangkan kondisi dan kemampuan subjek penelitian selain pada komponen set komponen waktu dalam hal ini repetisi. Prinsip progresivitas diberlakukan untuk proses adaptasi secara fisiologis.

Tabel 2 menjelaskan terkait program yang diberikan kepada subjek penelitian dengan modalitas intervensi Neuromuscular Electrical Stimulation (NMES) yang diberikan secara bersamaan dengan latihan forward lunges dan squat atau diberikan dengan prinsip kombinasi.

Prinsip pemberian modalitas ini sama halnya dengan modalitas latihan, yaitu dengan peningkatan dosis sesuai dengan waktu pelaksanaan proses penelitian lapangan, yaitu dengan perubahan pada mode frekuensi untuk intensitas yang dipertahankan dalam mode kuat.

Instrumen wall sit test seperti yang ditunjukan pada Tabel 3 digunakan untuk mengevaluasi daya tahan otot tungkai. Evaluasi dilaksanakan pada saat baseline, evaluasi berkala, serta follow up (satu bulan setelah tidak menerima paparan intervensi).
Tabel 1. Dosis Latihan Forward Lunges dan Squat

\begin{tabular}{|c|c|c|c|c|c|}
\hline No & Mgg & F & Int & Time & Tipe \\
\hline 1 & 1 & $\begin{array}{l}3 \text { kali } \\
\text { dalam } \\
\text { satu } \\
\text { minggu }\end{array}$ & 1 Set & $\begin{array}{l}15 \text { Repetisi } \\
\text { Rest } \\
\text { Interval antar } \\
\text { set: } 0 \text { Detik }\end{array}$ & $\begin{array}{l}1 . \\
\text { Forward } \\
\text { Lunges } \\
2 . \\
\text { Basic Squat }\end{array}$ \\
\hline 2 & 2 & $\begin{array}{l}3 \text { Kali } \\
\text { dalam } \\
\text { satu } \\
\text { minggu }\end{array}$ & 2 Set & $\begin{array}{l}15 \text { Repetisi } \\
\text { Waktu } \\
\text { istirahat antar } \\
\text { set: } 30 \text { detik }\end{array}$ & $\begin{array}{l}1 . \\
\text { Forward } \\
\text { Lunges } \\
2 . \\
\text { Basic Squat }\end{array}$ \\
\hline 3 & 3 & $\begin{array}{l}3 \text { Kali } \\
\text { dalam } \\
\text { satu } \\
\text { minggu }\end{array}$ & 2 Set & $\begin{array}{l}20 \text { Repetisi } \\
\text { Waktu } \\
\text { istirahat antar } \\
\text { set: } 1 \text { menit } \\
\text { (Fase } \\
\text { konsentrik } 4 \\
\text { hitungan) } \\
\text { dan Eccentric } \\
8 \text { hitungan) }\end{array}$ & $\begin{array}{l}1 . \\
\text { Forward } \\
\text { Lunges } \\
2 . \\
\text { Basic Squat }\end{array}$ \\
\hline 4 & 4 & $\begin{array}{l}3 \text { Kali } \\
\text { dalam } \\
\text { satu } \\
\text { minggu }\end{array}$ & 3 Set & $\begin{array}{l}20 \text { Repetisi } \\
\text { Waktu } \\
\text { istirahat antar } \\
\text { set: } 1 \text { menit } \\
\text { (Fase } \\
\text { konsentrik } 4 \\
\text { hitungan) } \\
\text { dan Eccentric } \\
8 \text { hitungan) }\end{array}$ & $\begin{array}{l}1 . \\
\text { Forward } \\
\text { Lunges } \\
2 . \\
\text { Basic Squat }\end{array}$ \\
\hline
\end{tabular}

\footnotetext{
Keterangan:

Mgg: Minggu

F: Frekuentsi
}

Int: Intensitas

Tabel 2. Dosis Neuromuscular Electrical Stimulation (NMES)

\begin{tabular}{|c|c|c|c|c|c|}
\hline No & Mgg & $\mathbf{F}$ & Int & Time & Tipe \\
\hline 1 & 1 & $\begin{array}{l}50 \mathrm{~Hz}, \\
3 x \text { per } \\
\text { minggu }\end{array}$ & $\begin{array}{l}\text { Kuat } \\
\text { sampai } \\
\text { tidak } \\
\text { nyaman }\end{array}$ & $\begin{array}{l}\text { Ramp } \\
\text { up time } \\
2 / 4\end{array}$ & NMES \\
\hline 2 & $2-3$ & $\begin{array}{l}40 \mathrm{~Hz}, \\
3 x / \\
\text { minggu }\end{array}$ & $\begin{array}{l}\text { Kuat } \\
\text { sampai } \\
\text { tidak } \\
\text { nyaman }\end{array}$ & $\begin{array}{l}\text { Ramp } \\
\text { up time } \\
2 / 4\end{array}$ & NMES \\
\hline 3 & 4 & $\begin{array}{l}35-50 \\
\mathrm{~Hz}, 3 x \\
\text { minggu }\end{array}$ & $\begin{array}{l}\text { Kuat } \\
\text { sampai } \\
\text { tidak } \\
\text { nyaman }\end{array}$ & $\begin{array}{l}\text { Ramp } \\
\text { up time } \\
2 / 4\end{array}$ & NMES \\
\hline
\end{tabular}

Keterangan:
Mgg: Minggu
F: Frekuentsi
Int: Intensitas

Tabel 3. Intepretasi Wall Sit Test (Detik) (Mackenzie, 2005)

\begin{tabular}{ccccccc}
\hline No & JK. & $\begin{array}{c}\text { Excel Above } \\
\text { lent }\end{array}$ & $\begin{array}{c}\text { Average } \\
\text { average }\end{array}$ & $\begin{array}{c}\text { Below } \\
\text { Average }\end{array}$ & Poor \\
\hline 1 & Putra & $>102$ & $102-76$ & $75-58$ & $57-30$ & $<30$ \\
2 & Putri & $>60$ & $60-46$ & $45-36$ & $35-20$ & $<20$ \\
\hline
\end{tabular}




\section{HASIL DAN PEMBAHASAN}

HASIL

Setelah dilakukanya kombinasi latihan eccentric dan NMES pada pemain badminton amatir berumur 18 tahun terhadap daya tahan otot tungkai selama 1 bulan dengan 12 sesi latihan yang dilakukan 3x per minggu dan dilakukan follow up pengukuran selama 1 bulan didapatkan peningkatan daya tahan otot tungkai yang diukur menggunakan wall sit test.

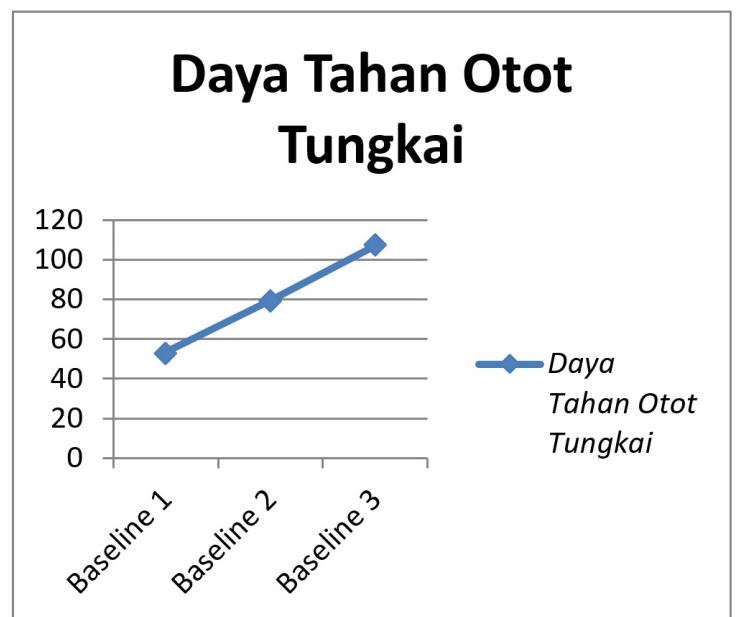

Gambar 2. Baseline Pengukuran Daya Tahan Otot Tungkai

Pengukuran baseline wall sit test dimulai tanggal 1 Juni 2020 dan diperoleh hasil 53,2 detik yang masuk dalam kategori below average. Pengukuran baseline kedua dilakukan tanggal 3 Juni 2020 dan terjadi peningkatan hasil yang didapatkan menjadi 79.6 detik dan masuk ke dalam kategori above average.

Pengukuran baseline ketiga dilakukan tanggal 5 Juni 2020 dan peningkatan hasil yang didapatkan signifikan, yaitu 107 detik dan masuk dalam kategori excellent. Hasil pengukuran baseline 1, 2, dan 3 secara keseluruhan menunjukkan peningkatan daya tahan otot tungkai pada pemain badminton amatir berumur 18 tahun.

Evaluasi pengukuran wall sit test dilakukan secara berkala. Evaluasi berkala dilakukan dengan tujuan mengetahui efek jangka pendek pemberian kombinasi latihan eccentric dan NMES pada pemain badminton amatir berumur 18 tahun terhadap daya tahan otot tungkai.

Pengukuran pertama dilakukan pada 15 Juni 2020 dan hasil tersebut yang didapatkan dibandingkan dengan baseline ketiga, yaitu 133 detik dan masuk kategori excellent. Hasil pengukuran kedua yang dilakukan pada 26 Juni 2020 yaitu 155 detik dan masuk kategori excellent. Pada pengukuran ketiga yang dilakukan pada 29 Juni 2020 didapatkan 178 detik dan masuk kategori excellent. Secara keseluruhan, pengukuran berkala wall sit test menunjukkan peningkatan hasil dibandingkan dengan baseline pengukuran.

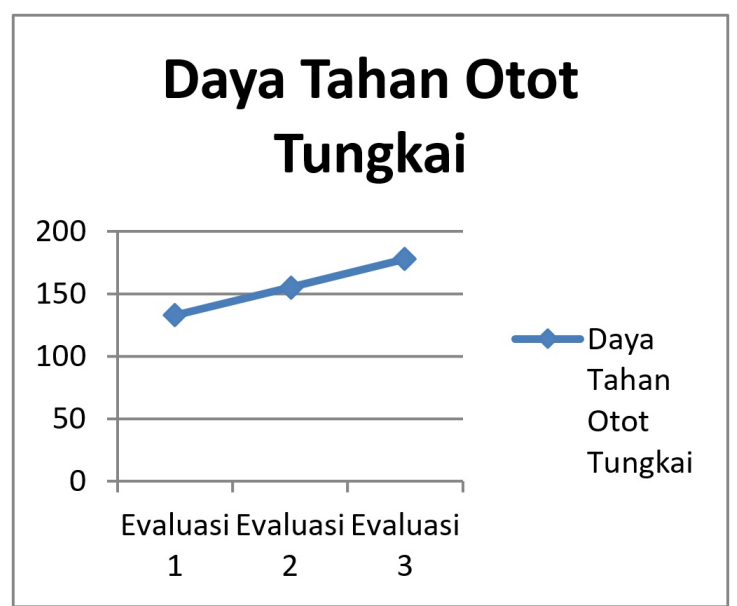

Gambar 3.Evaluasi Berkala Pengukuran Daya Tahan Otot Tungkai

Follow up pengukuran dilakukan untuk mengetahui efek jangka panjang setelah diberikan kombinasi latihan eccentric dan NMES pada pemain badminton amatir berumur 18 tahun terhadap daya tahan otot tungkai. Follow up pertama dilakukan tanggal 6 Juli 2020 dan hasil yang didapatkan 137 detik dan mengalami penurunan dibandingkan pengukuran wall sit test berkala pada tanggal 29 Juni 2020. Akan tetapi, hasil ini tetap masuk kategori excellent.

Follow up kedua dilakukan pada tanggal 20 Juli 2020 dan peningkatan hasil yang didapatkan 165 detik dan masuk kategori excellent. Follow up ketiga dilakukan pada tanggal 27 Juli 2020 dan peningkatan yang didapatkan signifikan dengan hasil 226 detik dan masuk kategori excellent. Hal ini menunjukan 
bahwa pemberian kombinasi latihan eccentric dan NMES pada pemain badminton amatir berumur 18 tahun memiliki efek jangka panjang terhadap peningkatan daya tahan otot tungkai.

Pada gambar 4 disajikan data terkait pengukuran daya tahan otot tungkai pada follow up satu, dua dan tiga.

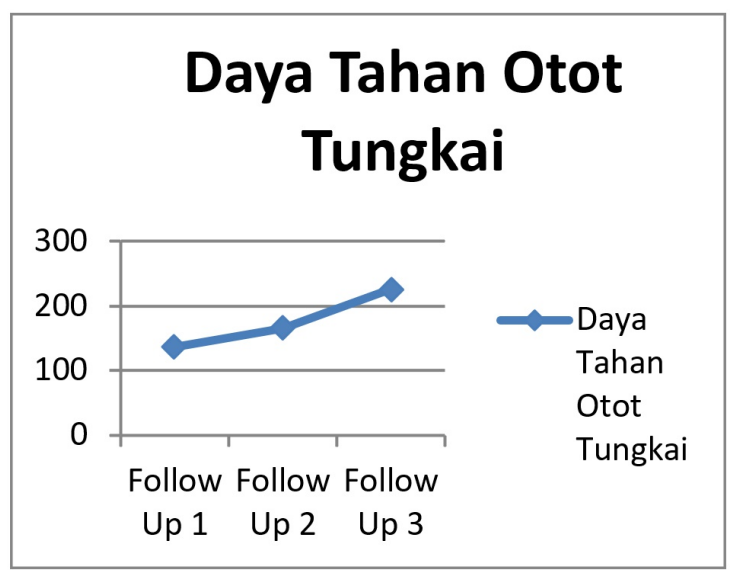

Gambar 4. Evaluasi follow up Pengukuran Daya Tahan Otot Tungkai

Proses evaluasi menggunakan wall sit test menunjukkan adanya peningkatan signifikan mulai dari baseline, evaluasi saat latihan, dan follow up selama 1 bulan setelah pemberian latihan ketika baseline didapatkan hasil 53,2 detik yang masuk dalam kategori below average.

Setelah diberikan latihan dan dilakukan evaluasi didapatkan peningkatan yang signifikan, yaitu 178 detik yang masuk dalam kategori excellent. Kemudian, follow up dilakukan selama 1 bulan dan menunjukkan adanya peningkatan hasil signifikan dari wall sit test yaitu 226 detik yang masuk dalam kategori excellent.

Adanya peningkatan hasil wall sit test menunjukkan bahwa terdapat efek jangka pendek dan jangka panjang pemberian kombinasi latihan eccentric dan NMES pada pemain badminton amatir berumur 18 tahun terhadap daya tahan otot tungkai.

Gambar 5 menjelaskan pengukuran daya tahan otot tungkai dengan capaian skor tertinggi pada setiap sesi pengukuran baseline, evaluasi berkala dan follow up (setelah satu bulan tidak terkena paparan intervensi)

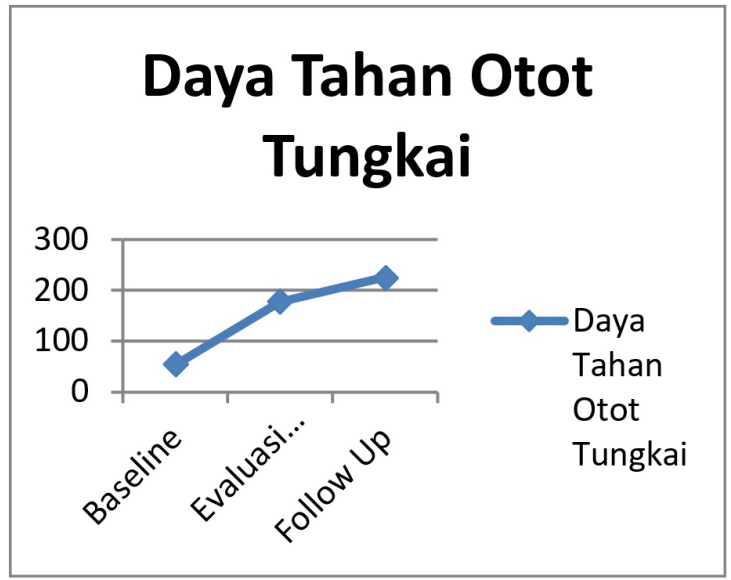

Gambar 5. Evaluasi Pengukuran Daya Tahan Otot Tungkai

\section{PEMBAHASAN}

Squat dan forward lunge merupakan suatu gerakan latihan yang digunakan pada banyak cabang olahraga yang membutuhkan strength dan power, misalnya badminton yang memerlukan komponen vertical jump dan kelincahan melangkah seperti yang dibahas dalam penelitian ini. Squat pada utamanya melatih kekuatan otot-otot punggung, pinggul, dan tungkai bawah, yang merupakan otot yang berperan penting pada gerakan berlari, melompat, dan mengangkat (Lorenzetti et al., 2018).

Otot yang bekerja dalam latihan squat adalah quadriceps, gluteus maximus, hamstring, hip adductors, hip abductors, gastrocnemius, soleus, tibialis anterior, rectus abdominis, dan erector spine (Bryanton et al., 2012).

Forward lunge dapat ditujukan kepada latihan yang menggunakan posisi tubuh manusia dimana satu tungkai digerakkan ke arah forward dengan fleksi lutut dan telapak kaki tetap di permukaan dan tungkai lain diposisikan di belakang (Mackenzie, 2005).

Badminton merupakan satu jenis olahraga yang melibatkan gerakan lunge pada permainan yang melibatkan banyak gerakan saat permainan. Pentingnya gerakan forward lunge dapat dilihat terutama saat pemain mencoba melakukan manuver drop shot dimana 
pemain perlu gerakan deep lunge untuk mendapatkan shuttlecock. Kemampuan ini penting untuk mengandalkan akselerasi pijakan untuk melakukan drop shot (Mackenzie, 2005).

Dalam gerakan squat dan lunges dinamis terjadi kontraksi otot secara eccentric \& concentric. Dalam kontraksi eccentric terjadi pemanjangan myofibril, sedangkan kontraksi concentric terjadi pemendekan myofibril (Clark \& Lucett, 2011). Pada otot skeletal, adaptasi fungsional latihan eccentric dapat didasarkan pada peningkatan massa otot, panjang fasik, jumlah sarkomer, dan luas penampang serat otot tipe II/fast twitch (Vogt \& Hoppeler, 2014).

Energi yang dihasilkan pada latihan fase eccentric memerlukan konsumsi ATP (Adenosin Trifosfat) yang lebih sedikit dibandingkan dengan fase konsentrik. Selain itu, fase eccentric mampu mempengaruhi keterlibatan filamen kontraksi otot berupa titin yang berpengaruh pada peningkatan kekuatan otot. Dengan demikian, latihan eccentric mampu meningkatan daya tahan otot tungkai bawah sehingga dapat menunjang performa pemain badminton.

Otot tipe II merupakan serabut otot yang mampu berkontraksi secara cepat. Serat otot tipe II ini hanya butuh waktu lebih singkat untuk mencapai kekuatan puncak dan dapat menghasilkan kekuatan yang lebih besar dibandingkan serat otot tipe I (slow twitch). Adaptasi fungsional tersebut dapat meningkatkan power otot yang dilatih, yang mana power otot tersebut sangat diperlukan untuk gerakan vertical jump.

Aktivitas otot eccentric juga memiliki fungsi mekanik yaitu shock absorber dan elastic spring yang berpengaruh pada gerakan jumping (Vogt \& Hoppeler, 2014). Otot dapat berperan sebagai shock absorber dimana fungsi ini dapat menghambat sendi yang akan bergerak ke arah berlawanan dengan memanfaatkan fungsi utamanya, yaitu kontraksi sehingga latihan kontraksi eccentric dapat menjadi program preventif pada cedera area knee (Hall \& Guyton, 2011).

Beberapa penelitian menyebutkan latihan eksentrik dapat meningkatkan fleksibilitas otot yang sedang dilatih dengan peningkatan ROM 1.67 derajat setelah program rehabilitasi selama 6 minggu. Dijelaskan dalam banyak literatur bahwa panjang otot yang dikatakan adequate merupakan faktor prinsip yang dapat melindungi cedera jaringan dan struktur vaskuler terkait (Álvarez-Ponce \& Guzmán-Muñoz, 2019).

Pada eccentric training terdapat mekanisme kontraksi eccentric yang mana myofilament dari serabut otot teregang saat kontraksi yang menyebabkan penautan yang mempengaruhi penambahan kekuatan (Santos et al., 2010). Latihan resistance dalam hal ini eccentric bermanfaat untuk perubahan neurologis meningkatkan kekuatan khususnya 8 minggu pertama.

Penelitian yang dilakukan oleh Irawan (2017) menemukan training dengan plyometric dengan salah satu komponen training eksentrik ekstensor knee memberikan peningkatan pada subjek sehat, khususnya variabel tes fungsional. Salah satunya ialah kemampuan kelincahan yang menjadi faktor pendukung penting bagi performa seorang pemain badminton dalam melakukan beberapa gerakan saat bertanding.

Eccentric training memiliki mekanisme kontraksi eccentric yang mana myofilament dari serabut otot teregang sehingga menyebabkan penurunan penautan crossbridge. Hal tersebut memengaruhi penautan cross-bridge saat terjadi kontraksi concentric, yang berakibat pada peningkatan power yang lebih besar disebabkan oleh elastic energy storage pada saat terjadi peregangan saat eccentric training (Yüksel et al., 2019).

$$
\text { Eccentric training terdapat }
$$
neurostimulation pada muscle spindle yang 
menyebabkan peregangan pada muscle spindle menghasilkan respon terhadap regangan dan kecepatan dari kontraksi. Semakin besar regangan maka akan semakin besar juga respon muscle spindle yang menyebabkan peningkatan kekuatan concentric pada serabut otot. Hal tersebut dapat memungkinkan peningkatan tinggi dari vertical jump (Yüksel et al., 2019).

Neuromuscular electrical stimulation (NMES) adalah aplikasi stimulus elektris menggunakan elektrode dipermukaan yang ditempelkan pada otot skelet untuk memproduksi kontraksi otot melalui aktivasi cabang saraf intramuscular (Imoto et al., 2013). NMES merupakan modalitas yang biasanya digunakan untuk melatih otot dan meningkatkan kekuatan otot terutama pasca cedera walaupun tidak ada batasan tertentu dalam penggunaan NMES.

Beberapa penelitian menemukan bahwa NMES lebih efektif bagi otot saat masa rehabilitasi setelah imobilisasi tetapi tidak lebih baik daripada latihan yang sifatnya konvensional untuk pemulihan massa otot atau untuk meningkatkan otot yang sehat (Glaviano \& Saliba, 2016).

Manfaat yang dapat ditemukan dari training NMES disebabkan oleh adaptasi otot terhadap stimulus saat training. Intervensi secara berulang-ulang akan memproduksi efek training yang dapat menurunkan ketidaknyamanan, kelelahan otot dan perkembangan enzim kreatin kinase dan parameter lain yang dapat membahayakan otot (Glaviano \& Saliba, 2016).

Efek tersebut akan memaksimalkan efek training dengan squat dan forward lunge exercise dengan prinsip eccentric di mana efek kedua training tersebut memberikan perubahan yang cukup signifikan pada aspek kekuatan otot, kelincahan dan kemampuan vertical jump pada pemain badminton.

\section{KESIMPULAN}

Berdasarkan hasil studi yang telah dilakukan, kombinasi knee eccentric exercise dan NMES dapat meningkatkan daya tahan otot tungkai secara umum pada pemain badminton amatir.

\section{DAFTAR PUSTAKA}

Akbari, M., Dlis, F., \& Widiastuti, W. (2018). The Effect At Muscle Power Arm, Hand-Eye Coordination, Flexibility and Self Confidence Upon Badminton Smash Skill. JIPES (Journal of Indonesian Physical Education and Sport), 4(1), 57-64. https://doi.org/ 10.21009/JIPES.041.05

Álvarez-Ponce, D., \& Guzmán-Muñoz, E. (2019). Effects of a program of eccentric exercises on hamstrings in youth soccer players. Archivos de Medicina Del Deporte, 36(1), 19-24. https://

archivosdemedicinadeldeporte.com/ articulos/upload/ or03_alvarez_ponce_ingles.pdf

Bryanton, M. A., Kennedy, M. D., Carey, J. P., \& Chiu, L. Z. F. (2012). Effect of Squat Depth and Barbell Load on Relative Muscular Effort in Squatting. Journal of Strength and Conditioning Research, 26(10), 2820-2828. https:// doi.org/10.1519/JSC.0b013e31826791a7

Carzoli, J. P., Sousa, C. A., Belcher, D. J., Helms, E. R., Khamoui, A. V., Whitehurst, M., \& Zourdos, M. C. (2019). The effects of eccentric phase duration on concentric outcomes in the back squat and bench press in well-trained males. Journal of Sports Sciences, 37(23), 2676-2684. https:// doi.org/ 10.1080/02640414.2019.1655131

Clark, M. A. ., \& Lucett, S. C. (2011). NASM's Essentials of Corretive Exercise Training. In Wolters Kluwer. Lippincott Williams \& Wilkins. http:// medbookshelf.info/nasm-essentialsof-corrective-exercise-training-1stedition/

Fu, L., Ren, F., \& Baker, J. S. (2017). Comparison of Joint Loading in 
Efek Kombinasi Latihan Eccentric dan Neuromuscular Electrical...

Badminton Lunging between Professional and Amateur Badminton Players. Applied Bionics and Biomechanics, 2017, 5397656. https:// doi.org/10.1155/2017/5397656

Glaviano, N. R., \& Saliba, S. (2016). Can the Use of Neuromuscular Electrical Stimulation Be Improved to Optimize Quadriceps Strengthening? Sports Health: A Multidisciplinary Approach, 8(1), 79-85. https://doi.org/ 10.1177/1941738115618174

Hall, J. E., \& Guyton, A. C. (2011). Guyton and Hall Textbook of Medical Physiology. Saunders. https://www.worldcat.org/ title/guyton-and-hall-textbook-ofmedical-physiology/oclc/434319356

Hong, Y., Wang, S. J., Lam, W. K., \& Cheung, J. T.-M. (2014). Kinetics of Badminton Lunges in Four Directions. Journal of Applied Biomechanics, 30(1), 113-118. https://doi.org/10.1123/jab. 2012-0151

Huang, H., Chatchawan, U., Eungpinichpong, W., \& Hunsawong, T. (2019). Progressive decrease in legpower performance during a fatiguing badminton field test. Journal of Physical Therapy Science, 31(10), 765770. https://doi.org/10.1589/jpts.31.765 Imoto, A. M., Peccin, S., Silva, K. N. G. da, Teixeira, L. E. P. de P., Abrahão, M. I., \& Trevisani, V. F. M. (2013). Effects of Neuromuscular Electrical Stimulation Combined with Exercises versus an Exercise Program on the Pain and the Function in Patients with Knee Osteoarthritis: A Randomized Controlled Trial. BioMed Research International, 2013, 1-7. https://doi.org/ $10.1155 / 2013 / 272018$

Irawan, D. (2017). Six Weeks Progressive Plyometrics Training on Badminton Player's Agility. Proceedings of the Health Science International Conference (HSIC 2017), 2(Hsic), 18-21. https:// doi.org/10.2991/hsic-17.2017.4

Lai, Z., Zhang, Y., Lee, S., \& Wang, L. (2018). Effects of strength exercise on the knee and ankle proprioception of individuals with knee osteoarthritis. Research in Sports Medicine, 26(2), 138146.

https://doi.org/ 10.1080/15438627.2018.1431541

Lepley, L. K., Wojtys, E. M., \& PalmieriSmith, R. M. (2015). Combination of eccentric exercise and neuromuscular electrical stimulation to improve biomechanical limb symmetry after anterior cruciate ligament reconstruction. Clinical Biomechanics, 30(7), 738-747. https://doi.org/10.1016/ j.clinbiomech.2015.04.011

Lorenzetti, S., Ostermann, M., Zeidler, F., Zimmer, P., Jentsch, L., List, R., Taylor, W. R., \& Schellenberg, F. (2018). How to squat? Effects of various stance widths, foot placement angles and level of experience on knee, hip and trunk motion and loading. BMC Sports Science, Medicine and Rehabilitation, 10(1), 14. https:// doi.org/10.1186/s13102-018-0103-7

Mackenzie, B. (2005). 101 Tests D'Évaluations. Electric Word plc. https://shahroodut.ac.ir/fa/ download.php?id=1111125195

Neyroud, D., Samararatne, J., Kayser, B., \& Place, N. (2017). Neuromuscular Fatigue After Repeated Jumping With Concomitant Electrical Stimulation. International Journal of Sports Physiology and Performance, 12(10), 1335-1340. https://doi.org/10.1123/ ijspp.2016-0571

Phomsoupha, M., \& Laffaye, G. (2015). The Science of Badminton: Game Characteristics, Anthropometry, Physiology, Visual Fitness and Biomechanics. Sports Medicine, 45(4), 473-495. https://doi.org/10.1007/ s40279-014-0287-2

Santos, H. H., Ávila, M. A., Hanashiro, D. N., Camargo, P. R., \& Salvini, T. F. (2010). The effects of knee extensor eccentric training on functional tests in healthy subjects. Brazilian Journal of Physical Therapy, 14(4), 276-283. 
https://doi.org/10.1590/S141335552010005000014

Vogt, M., \& Hoppeler, H. H. (2014). Eccentric exercise: mechanisms and effects when used as training regime or training adjunct. Journal of Applied Physiology (Bethesda, Md.: 1985), 116(11), 1446-1454. https://doi.org/ 10.1152/japplphysiol.00146.2013

Wong, T. K. K., Ma, A. W. W., Liu, K. P. Y., Chung, L. M. Y., Bae, Y.-H., Fong, S. S. M., Ganesan, B., \& Wang, H.-K. (2019). Balance control, agility, eyehand coordination, and sport performance of amateur badminton players: A cross-sectional study. Medicine, 98(2), e14134. https://doi.org/ 10.1097/MD.0000000000014134

Yüksel, O., Erzeybek, M. S., Kaya, F., Akın, S., \& Kirazcl, S. (2019). The Effect of Eccentric Strength and Depth Jump Training on Strength, Vertical Jump, and Modified Y Balance on Male Basketball Players. International Journal Of Applied Exercise Physiology, 8(3.1), 313-320. https:// open.metu.edu.tr/handle/11511/55335 